Citation: Grabovska, I. (2020). Contact-maintaining metacommunicative listener questions in modern English dialogic discourse. Cognitive Studies / Études cognitives, 2020(20), Article 2182. https://doi.org/10.11649/cs . 2182

\section{INNA GRABOVSKA}

National University of Life and Environmental Sciences of Ukraine, Kyiv, Ukraine https://orcid.org/0000-0002-4229-6298

ivgrabovska@gmail.com

\title{
CONTACT-MAINTAINING METACOMMUNICATIVE LISTENER QUESTIONS IN MODERN ENGLISH DIALOGIC DISCOURSE
}

\begin{abstract}
The paper focuses on revealing the mechanisms of maintaining spoken interaction by means of the metacommunicative listener questions in modern English dialogic discourse. The pragmatic and discursive properties of metacommunicative questions functioning at the contact-maintaining stage of the communicative act are singled out. The typology of contact-maintaining metacommunicative listener questions in modern English dialogic discourse is proposed. Contact-maintaining metacommunicative questions are viewed as a specifically oriented functional class of speech units bound by a common communicative purpose, i. e., they aim to control the communicative activity of the interlocutor, regulate the thematic and expressive components of the communicative situation, and to change the interpersonal relations of communication partners, thereby influencing the flow of interaction.

Keywords: metacommunication; phatic function; communicative contact; metacommunicative question; listener contact-maintaining metacommunicative question; echo-question; verifying question; dialogic discourse
\end{abstract}

\section{Introduction: Defining metacommunicative questions}

Modern linguistics is characterized by the study of the functioning of language units in a certain communicative-pragmatic dimension, in which the speaker and the listener interact in the process of object-practical and theoretical cognitive activity. This interaction does not occur for its own sake. Ultimately, the main function of speech activity is not the exchange of information, but the positive influence of one person on another. One feature of such interactions at the regulatory level is the use of metacommunicative questions, the basic differential semantic feature of which is desemantization, i. e., semantic emptiness.

Linguists have repeatedly drawn attention to a special group of questions that differ in their semantics and pragmatics from other types of questions (Chakhoian, 1979, p. 79; Fedotova, 2004, p. 67; Grabovskaia, 2013; Joos, 1967, p. 22; Krasnykh, 1997, p. 75; Lindstrem, 2003, p. 119; Paducheva, 1985, p. 233; Restan, 1972, pp. 138-139; Volkova, 1998, p. 55). Among questions aimed 
at creating a positive attitude, N. Yu. Shvedova (Shvedova, 1980, p. 396) highlighted questions whose purpose is to increase attention, interest the interlocutor, and focus on the form of thought expression. P. Restan (Restan, 1972, pp. 138-139) is correct to state that in the semantic classification of interrogative sentences "contact questions" are identified as interrrogative sentences that contain predicates with the meaning of sensory perception and mental activity, e. g., "You know what?" Such questions are asked not for the purpose of receiving an answer from the addressee, but for the purposes of liveliness of speech and the maintenance of communicative contact as a system of links of acoustic, psychological and socio-etiquette nature, which ensure the successful flow of interaction:

(1) Phil: Maybe she's right if the school has that kind of attitude.

Clara: You know what? All we ever end up talking about is Ollie or work. Let's just focus on us tonight.

Phil: Great. I'm all for that (Klausner, 2010).

Some researchers have identified the following categories of metacommunicative questions: a) regulatory questions that contribute to maintenance of interaction: they call the addressee to repeat or rephrase statements in the case when the addressee did not hear or did not understand the previous statement of the speaker (Joos, 1967, p. 22); b) interrogative-phatic utterances, the purpose of which is to attract the attention of the interlocutor, induce conversation, or to testify to the correctness of the speaker's observations (Volkova, 1998, p. 55); c) phatic questions as interrogative in their form statements that trigger a mental-cooperative reaction from the recipient. The main pragmatic function of such utterances is the phatic (contact-establishing) function (Lindstrem, 2003, p. 119); d) contact-establishing questions that are used to convince the interlocutor, increase attention, or create the effect of the interlocutor's complicity in the communicative process (Fedotova, 2004, p. 67). Despite their different definitions, these questions are all metacommunicative in nature.

The metacommunicative nature of certain types of questions was first discovered in the work of T. D. Chkhetiani (Chkhetiani, 1987, p. 100), who introduced the concept of the metacommunicative question, i. e., questions which are not informative but which instead have a contactestablishing purpose. Despite the fact that metacommunicative questions contain interrogative elements in their structure, they are statements in their content and do not express a request for information. These are pseudo-questions (Arliss, 1991, p. 56; Firth, 1972, p. 276; Pomerantz, 1980, p. 127; Wardsworth, 2012, p. 88), i. e, metacommunicative questions are speech units that are interrogative in their form and metacommunicative in their content, the main pragmatic functions of which are the establishment, maintenance and termination of the communiative contact. Let us consider this statement in more detail.

If the functional-communicative analysis of interrogative sentences is conducted on the basis of the study of their role in speech activity, then the semantic analysis of interrogative sentences is conducted on the basis of the criterion of whether they request unknown information or not. In terms of the semantics of interrogative sentences, some scholars traditionally distinguish between: a) information-seeking questions, the aim of which is to request information and to receive an answer; and b) pseudo-informative questions that do not have the purpose of requesting information (Blokh, 2002; Chakhoian, 1979, p. 386; Hedz, 1998, p. 3; Krasnykh, 1997, p. 75; Lindstrem, 2003, p. 14; Restan, 1972).

The division of questions into informative and pseudo-informative, the criterion of which is a request for information, is questionable. A more accurate division would be between informationseeking questions and non-information seeking questions. The latter are more likely to be pseudointerrogative than pseudo-informative, since they assert certain information in an interrogative form.

Information-seeking questions aim to fill a certain gap in the competence of the speaker, i. e, receiving an answer that satisfies its absence. For example: 
(2) Gabe: When are we gonna put up the Christmas tree?

Holly: This week (Macomber, 2010, p. 127).

In this study such questions, the main purpose of which is to obtain from the addressee information that is unknown to the addresser, are referred to as communicative questions. In contrast to communicative questions, metacommunicative questions are pseudo-questions in the sense that they do not contain information requests. In terms of content, metacommunicative questions are statements but in terms of form they are questions. Metacommunicative questions allow one to identify the position or purpose of the speaker concerning a subject of a request that is more an ascertainment than a request, and prompt the listener to give an answer to a question. On the one hand, among such types of questions disjunctive questions, which express a request to confirm the speaker's opinion, are clearly distinguishable (He has gone, hasn't he?). On the other hand, they are similar to rhetorical questions (What is the use of crying?), the answers to which are superfluous.

Metacommunicative questions, in addition to expressing the communicant's interest to the interlocutor's message, formally do not stop being questions and therefore require a certain reaction from the interlocutor. Like communicative questions, the main purpose of which is to obtain the information necessary for the addressee, metacommunicative questions have inherent semantics of will expression, which encourages a "response" (in terms of E. Goffman; Goffman, 1983, p. 35) a signal that indicates the presence of communicative contact (Oh, yes, how interesting), but which are not informatively meaningful answers ("replies" in terms of E. Goffman; Goffman, 1983, p. 35). In other words, the aim is to receive information as a verbal information-significant message and metainformation, i. e., information about information. This, in particular, is confirmation of the listener's attention to the transmitted message. A response indicates that the previous utterance has been perceived, understood, its contents deciphered, and that the listener knows that the speaker had a goal when performing the speech action. For example:

(3) Mr. Za: Just remember to be polite, not to speak out of turn, and that we all owe the Prince the utmost respect and attention, as he is our host and protector. Is that clear to you?

Aicha: Yes, Mr. Za, it is perfectly clear (Tremblay, 2009).

Therefore, metacommunicative questions are to be understood as questions which do not transmit information, but which instead only contribute to the transmission of propositionally significant information and serve the purposes of contact-establishment, contact-maintenance and contact-termination.

\subsection{Criteria for identifying metacommunicative questions}

The criteria for identifying metacommunicative questions include the following key features:

- the stage of the communicative contact. Metacommunicative questions are used to initiate, maintain and terminate a conversation. For example:

(4) [A slightly built, effeminate inmate (Samuel) raps on Phillip's open cell door as he enters.]

Samuel: Got a minute?

Phillip: Samuel. You want some crackers?

Samuel: No... thanks. Look - I just talked to my friend - he's a nurse at the infirmary. I don't know if you know this or not but uh... (Ficarra \& Requa, 2008).

The metacommunicative interrogative cliché Got a minute? performs the function of establishing the communicative contact with the interlocutor through the use of a polite request for the opportunity to communicate; 
- the metacommunicative questions' affiliation to the producer (speaker / addresser) or the recipient (listener / addressee) of the statement. The speaker's metacommunicative questions contain a direct or indirect incentive to maintain the listener's attention at the required level of information transmission. The listener's metacommunicatve questions confirm their focus on demonstrating interest in what the speaker is reporting. For example:

(5) Nelson: The rift with her family? That's what it's about, isn't it? Her rules? Oh come on, Chas, I love her too, you're not betraying her.

[Chas studies Nelson, nods.]

Chas: Yes. She saw what was coming, but they wouldn't let go, kept trying to run her disease. So she took off (Voelker, 2000).

The metacommunicative disjunctive question That's what it's about, isn't it? is a pseudoquestion, because it implies an unambiguous answer and provides only confirmation of the speaker's statement by the listener (Chas nods his head affirmatively and agrees with the speaker's statement);

- incentive semantics, which induces a response (information about information). For example:

(6) Maman: Your destiny is in your hands, bhai. You can be me. Or nobody. Understand?

Salim: Yes, Maman (Beaufoy, 2007).

The response Yes, Maman functions as a metacommunicative perceptual signal. With the help of this replica, the addressee signals that the contents of the addresser's message are clear to him and have been taken into account. In addition, the response expresses agreement with the previous statement of the speaker.

\subsection{Research methodology}

This paper focuses on revealing the mechanisms of communicative contact-maintenance via the listener's use of metacommunicative questions, with an emphasis on their semantic and functional specifics in modern English dialogic discourse. In order to do so it is necessary to ascertain what types of contact-maintaining metacommunicative listener questions, selected from the aforementioned corpus, are the most typical for this discourse type.

To achieve the research objectives, a number of general scientific methods (hypothesis, deduction, induction, analysis and synthesis), linguistics methods (semantic, pragmatic, contextualsituational, communicative-functional, and discourse analyses) and mathematical analyses (the quantitative method) were used. The application of these methods was complex, since at each stage of the study their combination was determined by the very adequacy of the goals and objectives of the investigation. Using the method of hypothesis, the probable structural, semantic, and functional features of the metacommunicative questions were proposed. The method of semantic analysis was used to establish the semantics of the contact-maintaining metacommunicative listener questions. The method of contextual-situational analysis was used to identify the discursive meanings of the contact-maintaining metacommunicative listener questions, in addition to the goals of the communicants and the social and role structures of interaction. Communicative-functional analysis enabled the study of the pragmatic functions of the contact-maintaining metacommunicative listener questions. The method of discourse analysis was used to establish the structure of modern English dialogic discourse, the order of speech moves in the dialogue, and the structure of speech action exchange. Quantitative analysis confirmed the predominance of particular types of contactmaintaining metacommunicative listener questions at the contact-maintaining stage of modern English dialogic discourse.

The research methodology of metacommunicative question investigation comprises four main stages. The number of stages is determined by the subject of the study and the tasks that are set 
in the paper, the solutions of which are necessary in order to achieve the aims of investigation. The first stage is the collection of factual material, the identification and differentiation of metacommunicative questions; the second stage is the description of the semantics of metacommunicative questions; the third stage is the investigation of the linguo-pragmatic features of metacommunicative questions; at the fourth stage the discourse-forming nature of metacommunicative questions is revealed. Thus, each stage covers a certain aspect of metacommunicative questions, which requires detailed research.

The purpose of the first stage was to conduct a continuous sampling of interrogative sentences from 53 English-language prose works from the $20^{\text {th }}$ and $21^{\text {st }}$ centuries and 100 scripts of Englishlanguage feature films of different genres, such as drama, melodrama, comedy, detective fiction, adventure, action, and science fiction, with a total page count of 33,143 . The material selected for linguistic investigation formed a corpus of 3,508 metacommunicative questions. In the course of processing the actual material, it was found that metacommunicative questions are inherent to three stages of communicative contact, namely establishment, maintenance and termination, which determine their functions.

During the second stage of the study, while revealing the functional and categorical specifics of metacommunicative questions, it was impossible to disregard the problem of metacommunicative question meaning, since the sequence "function - structure - meaning" is a combination of essential features that provide the basis for distinguishing metacommunicative questions as special functional and semantic units of the language system. The semantic structure of contactmaintaining metacommunicative questions in the communicative phatic situation "Continuation of a conversation" can be represented conditionally as follows: the speakers signal to the listeners that they are carrying out phatic communication, the listeners confirm that the communicative channel is working and that they perceive the speakers' messages.

Taking into account the focus of the cognitive-discursive paradigm of scientific knowledge on the identification of the regulatory aspect of spoken interaction, not only the linguistic aspects of contact-maintaining metacommunicative questions, but also the conditions in which they are implemented, i. e., the context of their usage, were investigated at the third stage. The solution to this problem was made possible by a thorough analysis of the dialogue of both feature films and novels as conditionally real persons in live communication against the background of their nonverbal behaviour at the stage of communicative contact-maintenance. Contact-maintaining metacommunicative questions control interlocutors' communicative activity, regulate the thematic and expressive components of the communicative situation, and change the interpersonal relationships of communication partners, thereby influencing the flow of communication.

The fourth stage of the study was devoted to the discursive analysis of metacommunicative questions, which is related to the methods of studying discourse. This type of analysis aims to consider metacommunicative questions in English dialogic discourse that contribute to its creation and regulation. The discursive functions of metacommunicative questions include: beginning the discourse, attracting to the discourse, developing the discourse, changing the topic of the discourse, picking up, seizing the initiative in the discourse, and ending the discourse. At this stage of the study, from the position of contact-maintaining metacommunicative questions' belonging to a producer or a recipient of a message, contact-maintaining metacommunicative questions of the speaker and the listener are distinguished. Contact-maintaining metacommunicative listener questions are feedback signals that indicate that the addressee is listening carefully to the speaker's message.

\section{Pragmatics of contact-maintaining metacommunicative lis- tener questions}

Contact-maintaining metacommunicative listener questions aim to implement the pragmatic principles of spoken interaction: the Principle of Cooperation (Grice, 1975) and the Principle of Poli- 
teness (Brown \& Levinson, 1987). By all means, an active and sincerely interested listener plays an important role in creating cooperative communication. The listener's utterances inform the speaker of the success or failure of the communicative contact. Conversely, the lack of listener feedback on the speaker's utterances may lead to dissonance, misunderstanding, or the emotional disturbance of the communicative partner. There is a set of language means specifically designed to maintain communicative contact on the part of the listener. They are represented by: a) echoquestions and b) verifying questions that ensure the change of the interlocutors' communicative roles. Taking into account the communicative context, only echo-questions and verifying questions that are asked formally were studied. With the help of echo-questions and verifying questions the listener turns from a passive participant into an active contributor to the dialogic discourse. Contact-maintaining metacommunicative listener questions confirm their focus on demonstrating interest in what speakers say. Consider in detail the two types of contact-maintaining metacommunicative listener questions - echo questions and verifying questions. The graph below illustrates the frequency of use of these two types in modern English dialogic discourse:

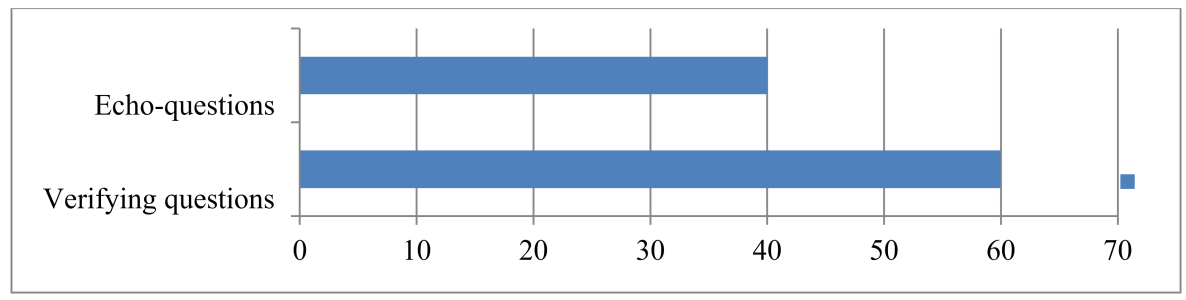

Figure 1: Frequency of use of contact-maintaining metacommunicative listener questions in modern English dialogic discourse.

\subsection{Contact-maintaining metacommunicative listener echo-questions}

Echo-questions $(40,05 \%)$ are used in dialogic discourse to maintain communicative contact (Hrabovs'ka, 2014). The echo-question is a phenomenon which contributes to the coherence of the dialogic discourse, supports phatic communion (Malinowski, 1999), and provides interpersonal engagement to the conversation. Researchers in the field of dialogic discourse syntax have unanimously come to the conclusion that the echo-question (an interrogative construction that completely repeats the speaker's previous statement) is one of the most characteristic types of structural-semantic connection of replicas within a dialogue (Arutiunova, 1986, p. 53; Chakhoian, 1979, p. 83; Chkhetiani, 1987, p. 146; Shvedova, 1980, pp. 68-70). Proceeding from this, echo-questions, as well as verifying questions, can be attributed to the grammatical-syntactic method of communicative contact maintenance, which comprises the complete repetition of the structure and verbal content of the speaker's previous utterance by keeping or changing its predicative relation. Consider this example:

(7) Suze: Well, you weren't getting very far with them, were you? I just thought I'd give you a helping hand.

Becky: A helping hand? [I echo weakly.]

Suze: I'll do the rest tomorrow, and then I'll ring up the delivery people. Pretty good, huh? (Kinsella, 2009, p. 119).

Metacommunicative echo-questions (due to their intonation contour they are also called "echoexchange"; Egner, 1996, p. 70), which serve as the listener's response reaction and do not require any active mental activity, automatically follow the speaker's initial utterance and express only an 
emotional attitude towards the propositional content of the previous utterance, help the addressee psychologically or at least do not prevent the speaker from taking another turn.

(8) Robyn: So, you'll come in through these double doors, and then the bugles will play ... or trumpets ... whatever you wish ... You'll pause in front of the grotto, arrange your train, have some photographs. And then the string orchestra will begin.

Becky: String orchestra? [I echo dazedly.]

Robyn: I've spoken to the New York Phil. They're checking their tour schedule, so, fingers crossed... (Kinsella, 2003, p. 47).

Echo-questions, the simplest and the most direct type of quotation, according to N. D. Arutiunova's figurative statement, are a "communicative boomerang". They add the prosodic predicate of evaluation to the speaker's utterance (Arutiunova, 1986, pp. 50-51). The speaker's speech activity, violated by the interlacement of metacommunicative echo-questions, can be easily restored, since such "catchphrases" (Chkhetiani, 1987, p. 148) are intuitively anticipated and are viewed as the stereotypical technique for maintaining communicative contact. Thus, metacommunicative echoquestions in the framework of phatic communication are specific speech acts associated with the emotional and psychological reaction of the listener to the content of the speaker's utterance. For example:

(9) Zelda: [...] Talk about your parents, how this has ruined their lives too ... problems in your childhood ... relationship trouble ... these are just ideas, obviously! And you know, if you were able to cry ...

Becky: To ... to cry? [I echo disbelievingly.]

Zelda: It's not compulsory. By any means. We want this to be a good experience for you too, Becky. We want to help. So we'd have Clare Edwards in the studio too, to offer you advice... (Kinsella, 2003, p. 203).

Researchers have different points of view on the role of echo-questions in dialogic discourse, which confirms the position on the diversity of their inherent functions (Arnol'd, 1990, pp. 184-187; Arutiunova, 1986, p. 50). Thus, some researchers view echo-questions as forced quotes of the previous replica, a hesitation, which is due to the carelessness of the interlocutor (Devkin, 1981, pp. 40-41). Obviously, such a characterization of echo-questions can only be applicable to cases of meaningful interchange of subject-logical information between the communicants. It does not in any way relate to the phenomenon of phatic metacommunication, in which the echo-question functions completely differently, gaining a positive influential effect. In this case, the usage of echo-questions is more likely to indicate the active involvement of the listener in the process of spoken interaction in a cost-effective intellectual manner and demonstrates an actual or implicit interest in the communication in order to maintain a conversation. This has been confirmed by researchers.

Echo-questions perform the function of a link in the sequence of initiative and responsive utterances of the speaker and the listener in spoken interaction and have a contact-maintaining character regardless of the stage of the communicative contact (Blokh, 2002). They create the impression of participation in a conversation, which not only helps to avoid silence, but also to express interest in the topic of conversation. For example:

(10) (Grandpa: Emma? I'm here. Just screening.

Emma: Screening? [I echo.] Grandpa-

Grandpa: Promise me you don't take London transport, Emma.

Emma: I er ... promise. Grandpa, I have to go, really. But I'll call again soon. Love you.

Grandpa: Love you too, darling girl (Kinsella, 2004, p. 93). 
In most cases echo-questions perform an interpersonal contact-establishing function, which ensures the consent of the communicants and the development of friendly relations. The function of positive interpersonal interaction is expressed with the help of the listener's complete repetition of the speaker's statement, but in an interrogative form. Such a permanent double structure is an example of a confirmatory exchange of replicas.

I. Egner (Egner, 1996, p. 70) investigates echo-questions as utterances inherent in verbal interpersonal interaction, phatic communication, indirect speech and formal communicative situations. Egner considers the following example, a dialogic interaction between a man of old age (R) and a young man $(\mathrm{F})$, which emphasizes the positive mood of the interlocutors at the establishment stage of the communicative contact. According to Egner, the echo-questions produced by the elder interlocutor are not information-seeking. They express recognition, gratitude, approval, and the positive attitude of the speaker towards the actions of the addressee:

(11) R: Where are you coming from?

$\mathrm{F}$ : I have just been clearing the road.

$\mathrm{R}$ : Have you just been clearing the road?

F: Yes.

R: Exactly what kind of clearing have you been doing?

F: I have been clearing a building plot.

R: Have you been clearing a building plot?

F: At the dawning of day very early this morning I left. Paul said a government officer is coming, so we have just been clearing a building plot up here.

R: Have you just been clearing a building plot up here?

F: Yes.

R: Thank you for your work.

F: Allright (Egner, 1996, pp. 70-71).

Echo-questions provide equality of the interlocutors in expressing points of view. It is like "a game" in which the communicants invite each other to speak out in turn. For example:

(12) Elinor: I was apprehensive.

Becky: Apprehensive? [I echo disbelievingly.]

Elinor: Giving up a child is a tremendous step. Taking a child back into one's life is ... equally momentous. Particularly after such a long time. I wasn't prepared for such a step. I wasn't prepared for seeing him (Kinsella, 2003, p. 236).

The regulatory function of echo-questions is to manage changes in the communicative role of the speaker and the listener, support the speaker's initiative, determine the topic of a conversation, and to terminate the speaker's statement. They do not develop the topic of spoken interaction in a meaningful way, but merely label it and thus demonstrate the interlocutor's interest in its continuation. In other words, echo-questions correspond to the discursive acts that perform the metacommunicative function of maintaining communicative contact in dialogic discourse. Consequently, they are also referred to as metaacts (Egner, 1996, p. 72) that regulate the speech process.

Echo-questions are used in order to avoid unintentional intermissions of the information flow in the process of communication through doubt, indecision or difficulties experienced by the speaker during a statement's production: 
(13) Parker: We have several areas that can be utilized for outdoor weddings. The most popular, especially for larger events is the west terrace and pergola. But...

Wyatt: But?

Parker: When I see the two of you, I picture something a little different. Something we do now and then. The pond. The willows, the roll of the lawns. I see a flower-strewn arbor and white runners flowing like a river between the rows of chairs - white again, strung with flowers. All of that reflected in the water of the pond (Roberts, 2010).

Parker Brown is engaged in organizing weddings and has prepared a project for the wedding in advance. However, during the meeting with the bride and the groom she had somewhat different opinions about the upcoming event and she began to hesitate about the previous plans. A pause in Parker's speech aroused the interest of the groom in the further development of the celebration. He used the echo-question But? to reveal his attention to the message of the interlocutor.

Thus, in terms of content, echo-questions can be viewed as redundant mean. However, from the point of view of pragmatics they are an essential means of cohesion and regulation of speech interaction. Echo-questions provide an appropriate use of replicas in the structure of the dialogue, contribute to the harmonization of relations between the interlocutors and maintain the communicative contact.

\subsection{Contact-maintaining metacommunincative listener verifying ques- tions}

Verifying questions are interrogative sentences, the actual information of which is not a new message but instead is the interlocutors' reaction to a message, the verification or correction of their thoughts (Adamets, 1966, p. 27; Dobrushina, 1993, p. 13). The purpose of verifying questions $(59.95 \%)$ is to receive confirmation or denial of the thought expressed by the interlocutor so that the communicative contact is not interrupted (Hrabovs'ka, 2014).

In syntactic structure, verifying questions are elliptical constructions with a direct or inverted order of the verbal and pronominal substitutions of the predicate and the subject. Therefore the replica-reaction must be perceived simultaneously with the replica-stimulus. For example:

(14) Holly: I'm sorry, Billy, but Gabe and I already have plans for tonight.

Gabe: We do?

Holly: We're going shopping (Macomber, 2010, p. 34).

Only the communicative functions of verifying questions, such as the establishment of the reality / unreality of a certain fact, or a request for the correctness of identification (Chakhoian, 1979 , p. 80) have been discussed so far. Verifying question cast doubt on the accuracy of the reported information and express the desire to know the essence of the matter or to reveal the true state of affairs, etc.

In addition to the communicative functions, a metacommunicative function is inherent in verifying questions. In the metacommunicative function verifying questions represent an exclusively formal grammatical tool which not intended to reveal the true state of affairs, but is only formally used to show the listener's interest in what is heard and, in accordance with the Principle of Politeness and Cooperation, to provoke the speaker to further narrative.

This idea is confirmed by O. A. Romanov's research (Romanov, 1988, p. 145), which proves that verifying questions aim to support the communication established by the partners. Questions of this type are multifunctional. The multifunctionality of verifying questions revolves around their involvement in the formation of regulative utterance that are used to control the flow of dialogical interaction - from the initial stage of contact establishment and its maintenance to the last stage of contact termination. 
Analysis of the collected material proves that verifying questions are short clichéd phrases such as Really?, Yeah?, You have?, You did?, You are?, which are accompanied or used in turn with other clichéd metacommunicative utterances such as How interesting!, Great!, Oh, great!, Ok, sure!, Glad to hear it!, That's so cool!, That's fantastic!, That's awesome!, Wow..., etc, expressing approval, or agreeing to the previous utterance of the speaker. For example:

(15) Abner: I've been thinking about something.

Nelson: You have? Glad to hear it.

Abner: I'm thinking: if you wanna adopt me, you can. Father-Son Day's on Monday. It would be good timing (Voelker, 2000).

(16) Tom: Yeah I quit the office.

Summer: Really? That's great! What are you doing now?

Tom: Mostly... sleeping. Breaking things (Neustadter \& Weber, 2009).

(17) Aaron: Why don't you show it to my Uncle Duncan? He's a doctor.

Nor man: He is? Great. Thanks (Rock \& Carr, 2009).

The main role of the verifying questions (You?, Really?, He is?) is to create an atmosphere of mutual benevolence so that the interlocutors feel constant trust from their partners in communication and do not try to question the joint contribution of the communicants in the agreed consent.

The pragmatic effect of listener verifying questions is that the maintenance of the communicative contact between the interlocutors is achieved at the expense of the speaker's creative verbal effort, while the listener exerts a minimum of creative verbal effort. The main functional purpose of verifying questions is that the listener only formally (Chkhetiani, 1987, p. 138) questions the truth of the content of the message, inviting the interlocutors to confirm what has been said and provide further explanation of the message, keeping them as the active speakers. For example:

(18) Emily: Well, a cashew is a rather unusual nut. My goodness, God was so creative with that one. Did you know the cashew is both a fruit and a nut?

Gabe: It is?

Emily: The fruit part looks like a small apple and it has a big stem. The stem part is the nut, the cashew (Macomber, 2010, p. 173).

The inverted verifying question It is? serves as the marker of the message's rheme The fruit part looks like a small apple and it has a big stem. The stem part is the nut, the cashew.

Verifying questions are pseudo-informative questions, because they are verifying only in form, not in content. The interlocutors are not interested in knowing whether the message is true or false, they are interested in maintaining the communicative contact uninterrupted, stimulating interest in what is being reported in a formal way. For example:

(19) Jake: I can't say for sure, but deep down I feel that if we were to walk away from each other right now, I'd regret it.

Holly: You do? Jake, I feel the same way (Macomber, 2010, p. 111).

It is common for verifying questions to transfer various types of subjective-modal evaluation. Emotional verification is an expression of verification value which employs interrogative sentences containing the listener's emotional response to the initial assumption of the replica-stimulus (to the fact that the speaker made such an assumption). It contains an indication of the truth or falsity of the speaker's message. For example: 
(20) Oliver: I'm trying to impress you.

Anna: [Gasps ironically.] Really? It's working. [They kiss.] (Mills, 2011).

So, with the help of metacommunicative verifying questions the listeners respond to the information in the speech flow, expressing their solidarity with the speakers' previous statement. Metacommunicative verifying questions regulate the process of communication and act as a material for filling lacunae of speech.

\section{Conclusions}

Contact-maintaining metacommunicative listener questions reflect the listener's emotional-evaluative attitude to the content of the speaker's message and determine the dynamics of the interaction. Metacommunicative verifying and echo-questions indicate the presence of acoustic, psychological and social-etiquette communicative contact between participants in spoken interaction. With the help of contact-maintaining metacommunicative questions, listeners demonstrate the degree of their interest in developing the thematic content of the interaction, encouraging the communication partner to continue verbal interaction on the proposed topic, thereby carrying out regulatory actions at the illocutionary-intentional and thematic levels.

\section{References}

Adamets, P. (1966). Poriadok slov v sovremennom russkom iazyke. Akademiia.

Arliss, L. P. (1991). Gender communication. Prentice-Hall.

Arnol'd, I. V. (1990). Stilistika sovremennogo angliǔskogo iazyka (stilistika dekodirovaniia). Prosveshchenie.

Arutiunova, N. D. (1986). Dialogicheskaia tsitatsiia: (K probleme chuzhoŭ rechi). Voprosy iazykoznaniia, $1986(1), 50-64$.

Beaufoy, S. (2007). Slumdog millionaire. The Internet Movie Script Database. http://www.imsdb.com/ scripts/Slumdog-Millionaire.html

Blokh, M. I. (2002). Teoreticheskie osnovy grammatiki. Vysshaia shkola.

Brown, P., \& Levinson, S. (1987). Politeness: Some universals in language usage. Cambridge University Press. https://doi.org/10.1017/CB09780511813085

Chakhoian, L. P. (1979). Sintaksis dialogicheskou rechi sovremennogo angliǔskogo iazyka. Vysshaia shkola.

Chkhetiani, T. D. (1987). Lingvisticheskie aspekty faticheskou metakommunikatsii (na materiale angliŭskogo iazyka) [Unpublished doctoral dissertation]. Kievskiı̌ gosudarstvennyı pedagogicheskiı̌ institut inostrannykh iazykov.

Devkin, V. D. (1981). Nemetskaia dialogicheskaia rech'v sopostavlenii s russkou. Vysshaia shkola.

Dobrushina, E. R. (1993). Verifikatsiia v sovremennő russkoŭ dialogicheskou rechi [Unpublished doctoral dissertation]. Moskovskiı̌ gosudarstvennyı̆ universitet imeni M. V. Lomonosova.

Egner, I. (1996). Other-repetition in question-form: Evidence from a West-African language. In C. Bazzanella (Ed.), Repetition in dialogue (pp. 66-77). Niemeyer.

Fedotova, V. I. (2004). Funktsional'no-pragmaticheskaia kharakteristika faticheskikh strategiu frantsuzskogo iazyka [Unpublished doctoral dissertation]. Piatigorskiŭ gosudarstvennyı̆ lingvisticheskiŭ universitet.

Ficarra, G., \& Requa, J. (2008). I love you Phillip Morris. The Internet Movie Script Database. http: //www.imsdb.com/scripts/I-Love-You-Phillip-Morris.html

Firth, R. (1972). Verbal and bodily rituals of greeting and parting. In J. S. La Fontaine (Ed.), The interpretation of ritual: Essays in honour of A. I. Richards (pp. 1-38). Tavistock.

Goffman, E. (1983). Forms of talk. University of Pennsylvania Press.

Grabovskaia, I. V. (2013). Teoreticheskiie osnovaniia izucheniia metakommunikativnykh voprosov v angloiazychnom dialogicheskom diskurse. Filologicheskie nauki: Voprosy teorii i praktiki, 7(25), 78-82. https://www.gramota.net/materials/2/2013/7-2/18.html

Grice, H. P. (1975). Logic and conversation. In P. Cole \& J. L. Morgan (Eds.), Syntax and semantics: Vol. 3. Speech acts (pp. 41-58). Academic Press. https://doi.org/10.1163/9789004368811_003 
Hedz, S. F. (1998). Komunikatyvno-prahmatychni osoblyvosti vyslovliuvan' z interohatyvnym znachenniam

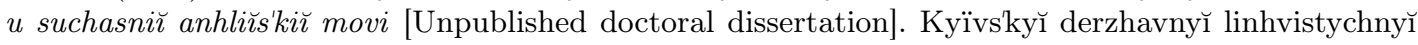
universytet.

Hrabovs'ka, I. V. (2014). Metakomunikatyvni pytannia v suchasnomu anhlomovnomu dialohichnomu dyskursi: Semantyka i prahmatyka [Unpublished doctoral dissertation]. Kyïvs'kyı̌ natsional'nyı̌ linhvistychnyı̌ universytet.

Joos, M. (1967). The five clocks: A linguistic excursion into the five styles of English usage. Harcourt, Brace and World.

Kinsella, S. (2001). Shopaholic takes Manhattan. Dial Press.

Kinsella, S. (2003). Shopaholic ties the knot. Dial Press.

Kinsella, S. (2004). Can you keep a secret? Dial Press.

Kinsella, S. (2009). Confessions of a shopaholic. Dell Publishing.

Klausner, J. (2010). Date night. The Internet Movie Script Database. http://www.imsdb.com/scripts/ Date-Night.html

Krasnykh, V. V. (1997). Voprosy v diskurse. In Lingvodidakticheskiie aspekty opisaniia iazyka i gibkaia model' obucheniia (pp. 75-78). Dialog-MGU.

Lindstrem, E. N. (2003). Klassifikatsiia russkikh voprositel'nykh po forme vyskazyvaniŭ na baze pragma-

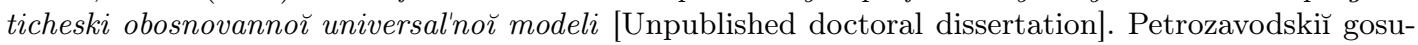
darstvennyı̆ universitet.

Macomber, D. (2010). Call me Mrs. Miracle. Mira.

Malinowski, B. (1999). On phatic communion. In A. Jaworski \& N. Coupland (Eds.), The discourse reader (pp. 302-305). Routledge.

Mills, M. (2011). Beginners. The Internet Movie Script Database. http://www.imsdb.com/scripts/ Beginners.html

Neustadter, S., \& Weber, M. H. (2009). 500 days of summer. http://www.cinefile.biz/script/ 500days of summer.pdf

Paducheva, E. V. (1985). Vyskazyvaniie $i$ ego sootnesennost' s deřstvitel'nost'iu. Nauka.

Pomerantz, A. (1980). Compliment responses: Notes on the co-operation of multiple constraints. In J. Schenkein (Ed.), Studies in the organization of conversational interaction (pp. 79-112). Academic Press. https://doi.org/10.1016/B978-0-12-623550-0.50010-0

Restan, P. (1972). Sintaksis voprositel'nogo predlozheniia: Obshchǐ vopros (glavnym obrazom na materiale sovremennogo russkogo iazyka). Universitetsforlaget.

Roberts, N. (2010). Happy ever after. Rewity. http://www.rewity.com/vb/t149684.html

Rock, C., \& Carr, A. (2009). Death at a funeral. The Internet Movie Script Database. http://www .imsdb. com/scripts/Death-at-a-Funeral.html

Romanov, A. A. (1988). Sistemny̆ analiz reguliativnykh sredstv dialogicheskogo obshcheniia [Summary of doctoral dissertation] Kalininskiı̆ gosudarstvennyı̌ universitet. http://cheloveknauka.com/ sistemny-analiz-regulyativnyh-sredstv-dialogicheskogo-obscheniya

Shvedova, N. I. (Ed.). (1980). Russkaia grammatika. Nauka.

Tremblay, I. (2009). Aicha. In I. Tremblay, Tales of inhumanity and retribution (pp. 1-108). AuthorHouse.

Voelker, K. (2000). Sweet November. The Daily Script. http://www.dailyscript.com/scripts/sweet_ november.pdf

Volkova, L. G. (1998). Faticheskaia funktsiia $i$ sintaksicheskiie sredstva ee realizatsii: Formal'ny̆, semanticheskiu, kommunikativno-pragmaticheskiu aspekt [Unpublished doctoral dissertation]. Tomskiŭ gosudarstvennyı universitet.

Wardsworth, M. (2012). The small talk handbook: Easy instructions on how to make small talk in any situation. Adams Media.

The publication was financed at the author's expense.

The author declares that she has no competing interests.

This is an Open Access article distributed under the terms of the Creative Commons Attribution 3.0 PL License (http://creativecommons.org/licenses/by/3.0/pl/), which permits redistribution, commercial and noncommercial, provided that the article is properly cited. 
(C) The Author 2020

Publisher: Institute of Slavic Studies, Polish Academy of Sciences

Publishing History: Received 2019-11-16; Accepted 2020-05-16; Published 2020-12-23. 